\title{
Article \\ Arbuscular Mycorrhizae Mitigate Aluminum Toxicity and Regulate Proline Metabolism in Plants Grown in Acidic Soil
}

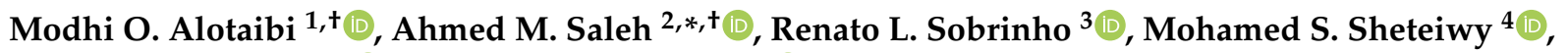 \\ Ahmed M. El-Sawah ${ }^{5}$, Afrah E. Mohammed ${ }^{1, *} \mathbb{1}$ and Hamada Abd Elgawad $6,7, *$ \\ 1 Department of Biology, College of Science, Princess Nourah Bint Abdulrahman University, \\ Riyadh 84428, Saudi Arabia; mouotaebe@pnu.edu.sa \\ 2 Department of Botany and Microbiology, Faculty of Science, Cairo University, Giza 12613, Egypt \\ 3 Department of Agronomy, Federal University of Technology, Pato Branco, Paraná 85503-390, Brazil; \\ rsobrinho@alunos.utfpr.edu.br \\ 4 Department of Agronomy, Faculty of Agriculture, Mansoura University, Mansoura 35516, Egypt; \\ salahco_2010@mans.edu.eg \\ 5 Department of Agricultural Microbiology, Faculty of Agriculture, Mansoura University, \\ Mansoura 35516, Egypt; ahmedelsawah89@mans.edu.eg \\ 6 Laboratory for Integrated Molecular Plant Physiology Research (IMPRES), Department of Biology, \\ University of Antwerp, 2020 Antwerp, Belgium \\ 7 Department of Botany and Microbiology, Faculty of Science, Beni-Suef University, Beni-Suef 62521, Egypt \\ * Correspondence: asaleh@sci.cu.edu.eg (A.M.S.); afamohammed@pnu.edu.sa (A.E.M.); \\ hamada.abdelgawad@uantwerpen.be (H.A.E.) \\ check for \\ + These authors contributed equally to this manuscript and share first authorship.
} updates

Citation: Alotaibi, M.O.; Saleh, A.M.; Sobrinho, R.L.; Sheteiwy, M.S.;

El-Sawah, A.M.; Mohammed, A.E.;

Elgawad, H.A. Arbuscular

Mycorrhizae Mitigate Aluminum

Toxicity and Regulate Proline

Metabolism in Plants Grown in

Acidic Soil. J. Fungi 2021, 7, 531.

https://doi.org/10.3390/jof7070531

Academic Editors: Raffaella

Maria Balestrini and Laurent Dufossé

Received: 26 May 2021

Accepted: 28 June 2021

Published: 30 June 2021

Publisher's Note: MDPI stays neutral with regard to jurisdictional claims in published maps and institutional affiliations.

Copyright: (c) 2021 by the authors. Licensee MDPI, Basel, Switzerland. This article is an open access article distributed under the terms and conditions of the Creative Commons Attribution (CC BY) license (https:// creativecommons.org/licenses/by/ $4.0 /$ )
Abstract: Arbuscular mycorrhizal fungi (AMF) can promote plant growth and induce stress tolerance. Proline is reported to accumulate in mycorrhizal plants under stressful conditions, such as aluminum (Al) stress. However, the detailed changes induced in proline metabolism under AMF-plant symbiosis has not been studied. Accordingly, this work aimed to study how Al-stressed grass (barley) and legume (lotus) species respond to AMF inoculation at growth and biochemical levels. The associated changes in $\mathrm{Al}$ uptake and accumulation, the rate of photosynthesis, and the key enzymes and metabolites involved in proline biosynthesis and degradation pathways were studied. Soil contamination with $\mathrm{Al}$ induced $\mathrm{Al}$ accumulation in tissues of both species and, consequently, reduced plant growth and the rate of photosynthesis, while more tolerance was noticed in lotus. Inoculation with AMF significantly reduced Al accumulation and mitigated the negative impacts of $\mathrm{Al}$ on growth and photosynthesis in both species; however, these positive effects were more pronounced in barley plants. The mitigating action of AMF was associated with upregulation of proline biosynthesis through glutamate and ornithine pathways, more in lotus than in barley, and repression of its catabolism. The increased proline level in lotus was consistent with improved $\mathrm{N}$ metabolism (N level and nitrate reductase). Overall, this study suggests the role of AMF in mitigating Al stress, where regulation of proline metabolism is a worthy mechanism underlying this mitigating action.

Keywords: lotus; barley; Rhizophagus irregularis; photosynthesis; proline metabolism; nitrogen assimilation

\section{Introduction}

Aluminum $\left(\mathrm{Al}^{3+}\right)$ toxicity is a major growth-limiting factor that restrains agronomic performance in acidic soils worldwide. About $25-80 \%$ of crop productivity loss is ascribed to $\mathrm{Al}$ effects $[1,2]$. In addition to the acidity that occurs naturally in soils, the use of nitrogen fertilizers also potentiates acidification processes through the conversion of $\mathrm{N}$-ammonium into nitrate by soil bacteria, releasing hydrogen $\left(\mathrm{H}^{+}\right)$, reducing the $\mathrm{pH}$ of the soil, and increasing the availability of $\mathrm{Al}^{3+}$ for plants [3,4]. In acidic soils $(\mathrm{pH} \leq 6), \mathrm{Al}^{3+}$ inters into plant roots, where it inhibits root cell division and elongation $[5,6] . \mathrm{Al}^{3+}$-stressed plants also experience a great reduction in the assimilation and uptake of water and nutrients, 
which consequently reduces their productivity $[7,8]$. The accumulation of $\mathrm{Al}$ in leaves directly induces specific stress responses in developmental, physiological, and biochemical processes. It disrupts the cell wall and plasma membrane structure, signal transduction, and nucleotide/phosphate homeostasis and alters the antioxidant and osmo-regulation status of plants $[9,10]$. Despite the agricultural impact of $\mathrm{Al}$ in soils, knowledge of the mechanisms of plant tolerance against $\mathrm{Al}$ toxicity is rather fragmentary.

Differences in responses to $\mathrm{Al}$ toxicity may originate from species differences, as different plant groups tend to react differently to heavy metal stress at different metabolic and physiological levels. For example, legumes, such Lotus corniculatus, show high tolerance to aluminum stress [11]. Lotus corniculatus is one of the most economically and ecologically important lotus species because it can effectively grow in polluted soils and thus is used for contaminated area restoration. However, grasses, such as barley (Hordeum vulgare L.), one of the major world crops based on production, are sensitive to $\mathrm{Al}$ toxicity. In this context, Ma et al. [12] screened about 600 barley lines from various regions of the world for their responses to $\mathrm{Al}$ toxicity and found that most screened lines are sensitive to $\mathrm{Al}$. Thus, it is important to understand how legumes and grasses differentially respond to $\mathrm{Al}$ accumulation in soil.

Plant tolerance to $\mathrm{Al}$ stress and soil acidity could be strengthened by symbiosis with arbuscular mycorrhizal fungi (AMF) [13-15]. AMF can provide a wide range of benefits to the host plant, such as forming a unique mycelial network, connecting plants of different species, regulating their growth, and allowing access to nutrients that would otherwise be unavailable [16]. AMF can also act as a physical barrier, capable of filtering and immobilizing toxic elements, in both extra- and intraradical fungal structures, thus mitigating the hazardous impacts of these phytotoxic elements [14,17]. From the metabolomic point of view, several mechanisms, direct and indirect, are suggested whereby AMF can stimulate plant growth and reduce the phytotoxicity of heavy metals [18,19], even in acidic soils that contain toxic levels of $\mathrm{Al}^{3+}[14,20]$. For instance, AMF can improve antioxidant defenses and the production of low-molecular-weight compounds, such as proline (Pro) [7,21]. Pro is one of the compatible solutes for osmotic adjustment, acts as a molecular chaperone stabilizing proteins and membranes under stress, and acts as a scavenger for reactive oxygen species (ROS) [22]. Pro is a key amino acid involved in a wide array of plant physiological and developmental processes $[23,24]$. In addition to its role in protein synthesis, it is known to act in stress mitigation [23,24]. Moreover, changes in Pro metabolism may affect the cellular redox status, prompting metabolic adjustments [25]. Pro can also contribute to buffering cytosolic $\mathrm{pH}$ and represents a source of energy, carbon, and nitrogen for plant growth after stress relief $[23,26]$. Pro biosynthesis in plants is associated with both the glutamate pathway and the ornithine (Orn) pathway [27]. In the glutamate pathway, Pro is synthesized in the cytoplasm, where glutamate is converted to 1-pyrroline-5-carboxylate (P5C) by $\Delta$ 1-pyrroline-5-carboxylate synthase (P5CS), which, in turn, is converted to Pro by $\Delta$ 1-pyrroline-5-carboxylate reductase (P5CR). The pathway from Orn-to-Pro production occurs in the mitochondria, where Orn is transaminated by Orn- $\delta$ aminotransferase (OAT), forming P5C and glutamate-semialdehyde, ending the transformation into Pro [23,27]. Although several studies have pointed to the accumulation of proline in mycorrhizal plants suffering metal stress, the detailed proline metabolism under combined metal and AMF treatments has been rarely investigated $[22,28]$. Therefore, the current study aimed to assess the detailed changes in Pro metabolism in AMF-plants influenced by $\mathrm{Al}^{+3}$ toxicity by monitoring the changes in the majority of metabolites and enzymes in the pathways of Pro biosynthesis and catabolism. To highlight species-specific responses, the role of AMF-plant symbiosis in the response of two different functional group species, i.e., barley (grass) and lotus (legume), was investigated. 


\section{Materials and Methods}

\subsection{Experimental Setup, Plant Materials, and Growth Conditions}

Homogeneous seeds of barley (Hordeum vulgare L. cv Giza 129) and lotus (Lotus corniculatus L cv Giza 171) were collected from the Agricultural Research Center, Giza, Egypt. Uniform and healthy seeds were sterilized by immersion for $20 \mathrm{~min}$ in sodium hypochlorite $(35 \%, v / v)$. After that, the seeds were germinated in Petri dishes and later transplanted to pots containing artificial soil with $65 \%$ water capacity and a $\mathrm{pH}$ of 5 , adjusted with $\mathrm{CaCO}_{3} . \mathrm{AlCl}_{3}$ solution was mixed with the soil in the following proportions: 0 (control) and 25 (stress) $\mathrm{mg} \mathrm{Al}^{+3} / \mathrm{kg}$ soil. For AMF treatment, the AMF spores used were Rhizophagus irregularis MUCL 41833; these were obtained from the in vitro collection of Glomeromycota (GINCO) (www.mycorrhiza.be/ginco-bel accessed on 2 February 2021). The inoculants of AMF were prepared using the methodology of El-Sawah et al. [29]. Briefly, AMF spores were grown for 6 months on the roots of Sorghum sudanenses Pers., and $5 \mathrm{~g}$ of trapped soil per plant or per pot (approx. 50 spores per $1 \mathrm{~g}$ soil) was added to each pot. The inoculum was inserted before sowing, at a depth of $5 \mathrm{~cm}$ below the surface, thus producing mycorrhizal treatment. The pots with no mycorrhiza (control) received equal amounts of autoclaved inoculum to guarantee the supply of the same nutrients. Then, control and treated soils were incubated in a growth chamber $(60 / 70 \%$ air humidity, $16 / 8 \mathrm{~h}$ day /night photoperiod, $21 / 18^{\circ} \mathrm{C}$ of air temperature, and $150 \mu \mathrm{mol} \mathrm{m}^{-2} \mathrm{~s}^{-1}$ light intensity). The plants were then grown in four experimental settings: (1) AMF $+0 \mathrm{mg}$ $\mathrm{Al}^{+3} / \mathrm{kg}$ soil (control); (2) soil inculcation with Rhizophagus irregularis MUCL 41833 (approx. 50 spores per $1 \mathrm{~g}$ soil) $+0 \mathrm{mg} \mathrm{Al}^{+3} / \mathrm{kg}$ soil (AMF); (3) $\mathrm{AMF}+25 \mathrm{mg} \mathrm{Al}^{+3} / \mathrm{kg}$ soil (Al); and (4) $\mathrm{AMF}+25 \mathrm{mg} \mathrm{Al}^{+3} / \mathrm{kg}$ soil $(\mathrm{Al}+\mathrm{AMF})$.

Each of the four groups was composed of 15 pots containing 10 plants each. The soils were watered daily, keeping the water content at $65 \%$ and the $\mathrm{pH}$ at 5 . Plants were harvested 4 weeks after planting in pots. To determine the dry mass and analyze the elements, some organs were harvested and washed carefully with double-distilled water and gently wiped with paper towels. They were then placed to dry at $75^{\circ} \mathrm{C}$ until they reached a fixed weight. The remaining samples were instantly frozen in liquid nitrogen and kept in a $-80^{\circ} \mathrm{C}$ freezer for future biochemical analyses. The entire experiment was repeated twice.

\subsection{Photosynthetic Rate}

The photosynthetic rate was evaluated using fully mature leaves, and the variables evaluated were light saturation, gas exchange, and the photosynthetic rate. These parameters were measured using a portable photosynthesis system (LI-COR LI-6400; LI-COR Inc., Lincoln, NE, USA) according AbdElgawad, et al. [30]. The photochemical efficiency $(\mathrm{Fv} / \mathrm{Fm})$ of non-cyclic electron transport in PSII was evaluated on 5 or 6 leaves adapted to the dark for 30 min using a fluorimeter (PAM2000; Walz, Effeltrich, Germany).

\subsection{Mycorrhizal Parameters}

Mycorrhizal colonization was verified according to the methodology of Phillips and Hayman [31]. Briefly, about $0.5 \mathrm{~g}$ of fresh roots was clarified with hydrogen peroxide + potassium hydroxide (10\%) in a ratio of $1: 1(v / v)$ and then subjected to $0.05 \%$ trypan blue dye in lactoglycerol. The roots were then evaluated under the microscope $(40 \times)$ to assess the presence of colonization. The colonization rate was calculated using the gridline intersect methodology. The abundance of arbuscules in the root system was calculated using the number of root arbuscules cm-1 according to Giovannetti and Mosse [32]. The length of the hyphae was determined by the method of Andrade et al. [33].

\subsection{Determination of Aluminum Content in Soil and Plant Tissue}

The aluminum level was evaluated in the soil and in the tissues of barley shoots. $\mathrm{Al}$ content was determined according to Giannakoula et al. [34]. The rhizosphere was obtained by shaking the roots gently to separate them from the soil, and then the soil 
attached to the thin roots ( $0-2$-mm-thick layer) was obtained gently by brushing. Then, $0.1 \mathrm{~g}$ of plant tissues and $5 \mathrm{~g}$ of soil were digested in a 4:1 $(\mathrm{v} / \mathrm{v})$ nitric acid/perchloric acid $\left(\mathrm{HNO}_{3} / \mathrm{HClO}_{4}\right)$ solution to be ready for analysis by inductively coupled plasma-atomic emission spectrometry (ICP-AES). After extraction, the aluminum content was determined using ICP-AES (PerkinElmer Optima 3300XL; PerkinElmer, Waltham, MA, USA). The internal rhodium standard was used with the addition of samples and calibration solutions.

\subsection{Amino Acid and Nitrogen Measurements}

The extraction of amino acids was performed using sprouts homogenized in $1 \mathrm{~mL}$ of $80 \%(v / v)$ aqueous ethanol, supplemented with norvaline, to control the loss of amino acids during extraction. Amino acid content was assessed using the Waters Acquity UPLC-tqd system (Waters Corporation, Milford, MA, USA) along with a $2.1 \times 50$ amide BEH column, as described by AbdElhawad et al. [35]. Nitrogen levels were assessed using a $\mathrm{CN}$ element analyzer (NC-2100; Carlo Erba Instruments, Milan, Italy).

\subsection{Enzyme Activity Assays}

The activities of pyrroline-5-carboxylate synthase (P5CS), pyrroline-5-carboxylate reductase (P5CR), glutamine synthetase (GS), and Pro dehydrogenase (ProDH) were evaluated in shoot system tissues after extraction in a buffer solution containing Tris- $\mathrm{HCl}(50 \mathrm{mM}$, $\mathrm{pH}$ 7.4) [36-38]. Arginase (ARG) and Orn aminotransferase (OAT) were evaluated after their extraction in a buffer solution containing potassium phosphate $(50 \mathrm{mM}, \mathrm{pH} 7.0)$. In the P5CS evaluation, the NADPH-dependent conversion of glutamate to 5-semialdehyde glutamate was evaluated. ATP was added to the mixture to ensure glutamate kinase (GK) activity. GK activity was not measured separately. ProDH and OAT activities were evaluated according to Sakuraba et al. [39] and Charest and Phan [40]. The arginase and Gly-NaOH reaction mixture was evaluated according to the methodology of Nuzum and Snodgrass [41]. NADH nitrate-dependent reductase activity (NR, EC 1.7.1.1) was evaluated with a mixture of $\mathrm{KPO}_{4}$ buffer solution (pH 7.6) containing $100 \mathrm{mM} \mathrm{KNO}_{3}$ and $1 \mathrm{mM}$ $\mathrm{NADH}$, and the oxidation of NADH in A340 was also evaluated. Nitrate reductase (NR) activity was assayed according to the method described by AbdElgawad et al. [42].

\subsection{Statistical Analysis}

All the data were subjected to one-way analysis of variance (ANOVA). Tukey's multiple-range test $(p<0.05)$ was carried out as the post hoc test for mean separations. The number of replicates for each vegetal species was three $(n=5)$. Principal component analysis (OriginLab 9, Northampton, MA, USA) and cluster analysis (Pearson distance metric; MultiExperiment Viewer $(\mathrm{MeV})^{\mathrm{TM}} 4$ software, La Jolla, CA, USA) of all results were performed.

\section{Results}

\subsection{AMF Colonization and Hyphal Growth}

Mycorrhizal colonization was highly affected by different tested treatments in both plants; however, no mycorrhizal colonization was observed in the roots of plants that were not inoculated with AMF (Table 1). The roots of barley and lotus were extensively colonized by AMF. Nonetheless, in the presence of aluminum, AMF colonization significantly reduced by $26.30 \%$ and $30.59 \%$ in barley and lotus, respectively. Further, the hyphal length in the rhizosphere soil of both plants reduced significantly by $27.37 \%$ and $46.44 \%$ in barley and lotus, respectively. In addition, the number of arbuscules in roots reduced in the presence of $\mathrm{Al}$ in the lotus plant but not in the barley plant. 
Table 1. Mycorrhizal colonization and growth parameters in roots of barley and lotus under normal conditions (control) and $\mathrm{Al}$ stress. Values are the mean \pm standard error of five independent replicates. Different letters indicate significant changes $(p<0.05)$ between AMF alone and combined AMF + Al treatment.

\begin{tabular}{|c|c|c|c|c|c|c|c|c|}
\hline \multirow{2}{*}{ Parameter } & \multicolumn{4}{|c|}{ Barley } & \multicolumn{4}{|c|}{ Lotus } \\
\hline & Control & AMF & Al & $\mathbf{A l}+\mathbf{A M F}$ & Control & AMF & Al & $\mathbf{A l}+\mathbf{A M F}$ \\
\hline AM colonization (\% per root) & 0 & $58.35 \pm 1 \mathrm{a}$ & 0 & $43.0 \pm 1.45 b$ & 0 & $55.9 \pm 1.6 \mathrm{a}$ & 0 & $38.8 \pm 1.7 \mathrm{~b}$ \\
\hline Hyphal length (mm/g soil) & 0 & $1943 \pm 98 a$ & 0 & $1411.2 \pm 12 b$ & 0 & $2168 \pm 198 a$ & 0 & $1161 \pm 101 b$ \\
\hline Arbuscules (number/cm root) & 0 & $4.8 \pm 0.703 a$ & 0 & $4.4 \pm 0.34 \mathrm{a}$ & 0 & $5.1 \pm 0.7 \mathrm{a}$ & 0 & $4.1 \pm 0.3 b$ \\
\hline
\end{tabular}

\subsection{Plant Biomass, Photosynthesis, and Al Accumulation}

The mean data regarding plant biomass, rate of photosynthesis, and $\mathrm{Al}$ accumulation, as affected by $\mathrm{Al}$ and AMF applications, are presented in Table 2. The obtained results showed that AMF treatment enhanced the growth of barley and lotus plants significantly. Under this treatment, the plants had an increase of $18 \%$ and $16 \%$ in the fresh mass and $52 \%$ and $18 \%$ in the dry mass in relation to the control treatment for barley and lotus plants, respectively (Table 2). Moreover, there was a significant change in photosynthesis after AMF treatment, with an increase of $18 \%$ for lotus plants; however, there was no significant change in photosynthesis for barley plants (Table 2). The treatment with $\mathrm{Al}$ increased the accumulation of $\mathrm{Al}$ ions in the tissues of barley and lotus plants and decreased the fresh mass, dry mass, and photosynthesis compared with individual mycorrhizal treatment (Table 2). For barley plants, Al reduced approximately $60 \%$ of fresh and dry masses, with a $70 \%$ reduction in photosynthesis compared with the control. For lotus plants, the presence of $\mathrm{Al}$ in the soil decreased the fresh mass, dry mass, and photosynthesis at mean values of $50 \%$ when compared with the control; this reduction was lower than that observed for barley. In addition, the treatment $(\mathrm{Al}+\mathrm{AMF})$ mitigated the negative effects of aluminum accumulation in both plants; however, this recovery was more pronounced in barley plants. Under $\mathrm{Al}+\mathrm{AMF}$ treatment, the fresh mass of barley plants was $73 \%$ higher than under $\mathrm{Al}$ treatment. The same behavior was also observed for the dry mass, with an increase of $88 \%$, and photosynthesis, with an increase of $100 \%$, in relation to $\mathrm{Al}$ treatment. However, the increase was more than $40 \%$ for the fresh and dry masses for lotus plants (Table 2).

Table 2. Impact of arbuscular mycorrhizal fungi (AMF), $\mathrm{Al}\left(12 \mathrm{mg} \mathrm{Al} \mathrm{kg}^{-1}\right)$, or their combination on fresh and dry masses

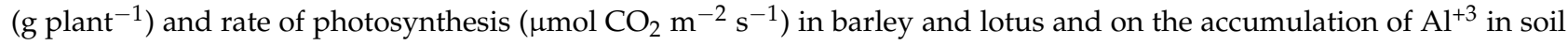
$\left(\mathrm{mg} \mathrm{g}^{-1}\right.$ soil) and in tissues of plant shoot $\left(\mathrm{mg} \mathrm{g}^{-1} \mathrm{DW}\right)$. Values are presented as the mean \pm standard error of at least five independent replicates. Different letters within the same plant indicate significant differences between means (Tukey's test; $p<0.05)$.

\begin{tabular}{ccccccccc}
\hline \multirow{2}{*}{ Parameter } & \multicolumn{9}{c}{ Barley } & \multicolumn{3}{c}{ Lotus } \\
\cline { 2 - 9 } & Control & AMF & Al & Al + AMF & Control & AMF & Al & Al + AMF \\
\hline Fresh weight & $2.03 \pm 0.1 \mathrm{c}$ & $2.4 \pm 0.15 \mathrm{~d}$ & $0.82 \pm 0.03 \mathrm{a}$ & $1.43 \pm 0.14 \mathrm{~b}$ & $2.68 \pm 0.05 \mathrm{c}$ & $3.11 \pm 0.2 \mathrm{~d}$ & $1.38 \pm 0.12 \mathrm{a}$ & $1.97 \pm 0.21 \mathrm{~b}$ \\
Dry weight & $0.44 \pm 0.02 \mathrm{~b}$ & $0.67 \pm 0.06 \mathrm{c}$ & $0.18 \pm 0.02 \mathrm{a}$ & $0.34 \pm 0.07 \mathrm{~b}$ & $0.64 \pm 0.01 \mathrm{c}$ & $0.76 \pm 0.08 \mathrm{~d}$ & $0.35 \pm 0.01 \mathrm{a}$ & $0.51 \pm 0.08 \mathrm{~b}$ \\
Rate of & $0.14 \pm 0.01 \mathrm{c}$ & $0.15 \pm 0.01 \mathrm{c}$ & $0.04 \pm 0.02 \mathrm{a}$ & $0.08 \pm 0.01 \mathrm{~b}$ & $0.19 \pm 0.01 \mathrm{~b}$ & $0.23 \pm 0.01 \mathrm{bc}$ & $0.09 \pm 0.01 \mathrm{a}$ & $0.17 \pm 0.02 \mathrm{~b}$ \\
photosynthesis & ND & ND & $164.84 \pm 22.95 \mathrm{~b}$ & $76.48 \pm 2.53 \mathrm{a}$ & ND & ND & $128.62 \pm 4.32 \mathrm{~b}$ & $90.11 \pm 11.41 \mathrm{a}$ \\
Al in tissues & ND & ND & $15.51 \pm 0.38 \mathrm{~b}$ & $08.86 \pm 1.19 \mathrm{a}$ & ND & ND & $16.24 \pm 1.62 \mathrm{~b}$ & $11.72 \pm 1.02 \mathrm{a}$ \\
Al in soil & \multicolumn{3}{c}{ ND: non-detected } & & &
\end{tabular}

\subsection{Proline Biosynthesis: Glutamine Pathway}

The data on P5CS, P5CR, and Pro levels in barley and lotus plants are presented in Figure 1. AMF inoculation did not significantly affect proline biosynthesis via the glutamine pathway in barley, but it increased proline biosynthesis in lotus by increasing the activities of GOGAT, GS, and P5CS. Consistent with the increase in GS and GOGAT activities, glutamine content decreased under AMF treatment (Figure 1). Al treatment increased Pro biosynthesis in barley and lotus by increasing the activities of GS, GOGAT, and P5CS enzymes in both plants, with a concomitant decrease in glutamine content 
(Figure 1). Co-application of $\mathrm{Al}$ and $\mathrm{AMF}$ treatments strengthened the impact of $\mathrm{Al}$ on GS and GOGAT enzyme activities, particularly in lotus. In contrast, AMF reduced the Al impact on glutamine and glutamate concentration in barley and did not affect P5CS enzyme activity in both species. The produced glutamate 5-semialdehyde was spontaneously converted to $\mathrm{P} 5 \mathrm{C}$, which was catabolized to glutamate by $\mathrm{P} 5 \mathrm{CDH}$ enzyme. The activity of $\mathrm{P} 5 \mathrm{CDH}$ did not alter in both AMF-treated species, but it decreased under $\mathrm{Al}$ treatment, and the co-application of AMF and $\mathrm{Al}$ further strengthened this impact.

$\square$ Control $\mathbf{D A M F} \square$ Al $\square$ Al+AMF

(A)

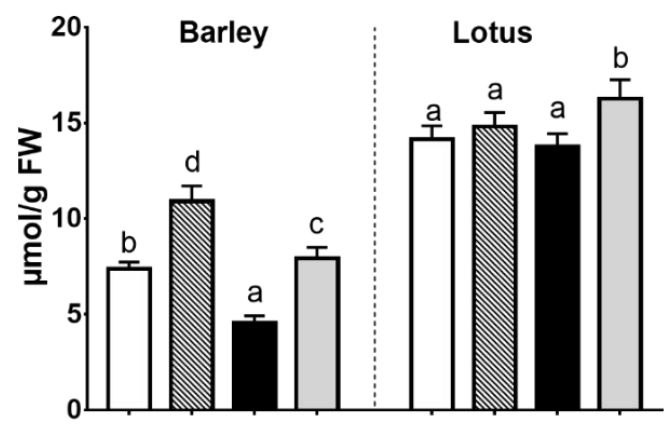

(C)

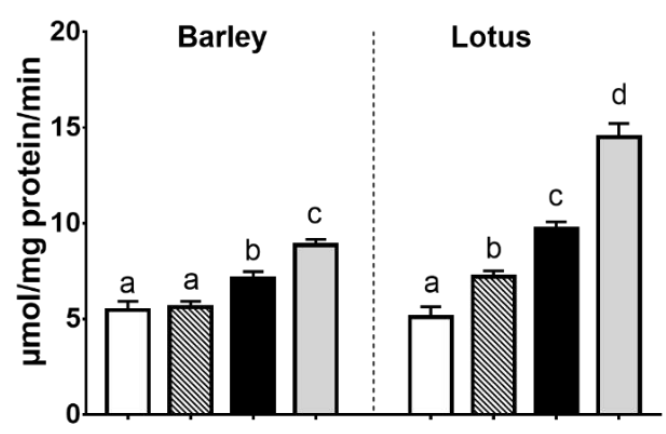

(E)

P5CS

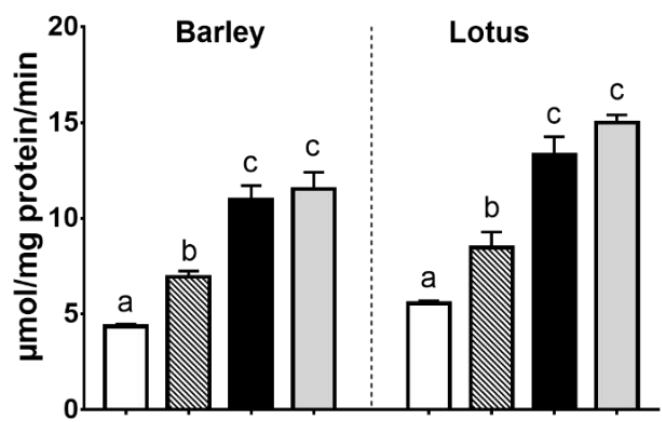

(B)

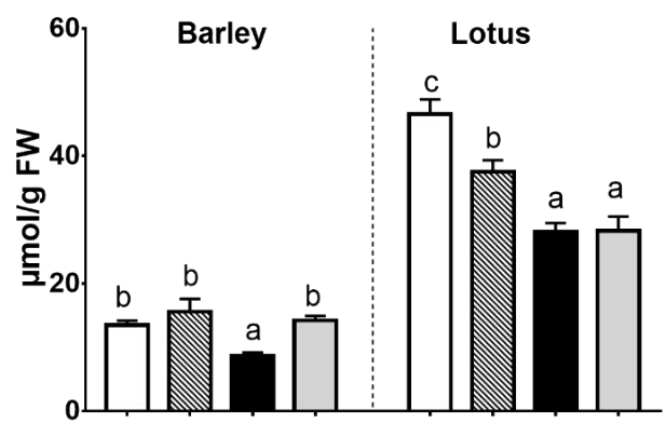

(D)

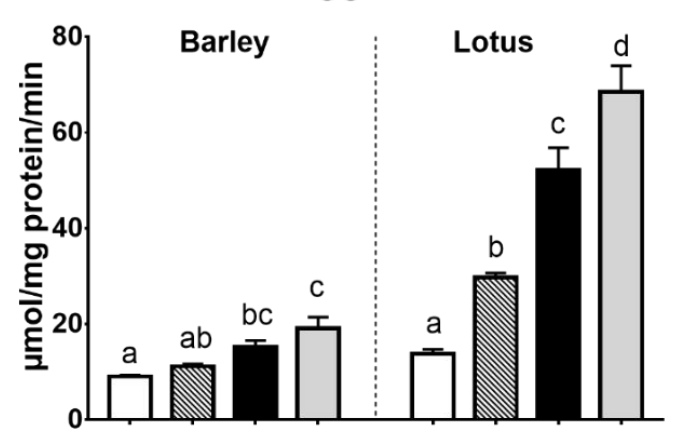

(F)

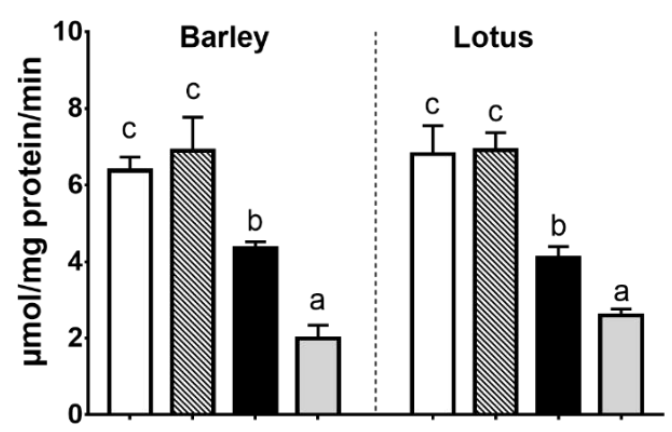

Figure 1. Proline biosynthesis (glutamate pathway). Changes in metabolic level and related enzyme activities: impact of arbuscular mycorrhizal fungi (AMF), $\mathrm{Al}\left(25 \mathrm{mg} \mathrm{Al} \mathrm{kg}^{-1}\right.$ soil), or their combination. Panels show concentrations of glutamate (A), glutamine (B), and the activity of glutamate synthase (GOGAT; (C)), glutamine synthetase (GS; (D)), P5C synthase (P5CS; (E)), and D1-pyrroline-5-carboxylate reductase (ProDH) (F). Different letters in each graph represent significant differences between the three treatments in each species (Tukey's test; $p<0.05 ; n=5$ ). 


\subsection{Proline Biosynthesis: Ornithine Pathway}

Arginine (Arg) and orninthine (Orn) provide precursors for the Pro synthesis pathway (Figure 2). AMF inoculation had no significant effects on the level of Arg in both species, whereas arginase and orninthine aminotransferase (OAT) significantly increased in lotus (Figure 2). Al stress had no impact on the arginine content in both treated species; however, Orn content reduced in lotus but not in barley. Co-application of AMF and Al did not significantly change the Al effect on the metabolic level of Arg and Orn. OAT activity increased in AMF- and Al-treated barley plants and to a greater extent in treated lotus plants (Figure 2), but this increase was not observed for arginase activity.

\section{$\square$ Control $\mathbf{D}$ AMF $\square$ Al $\square$ Al+AMF}

(A)

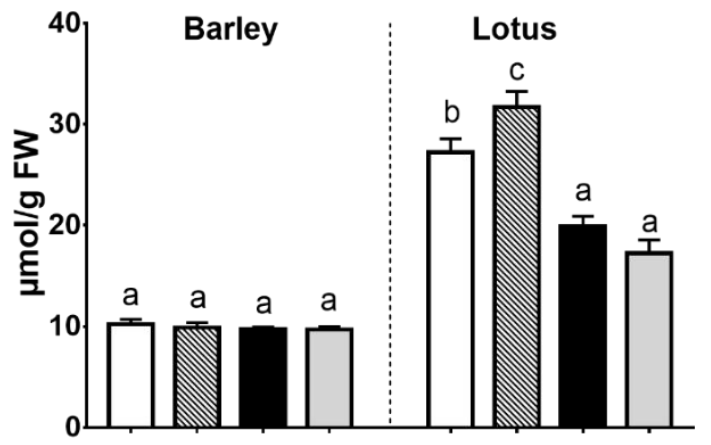

(C)

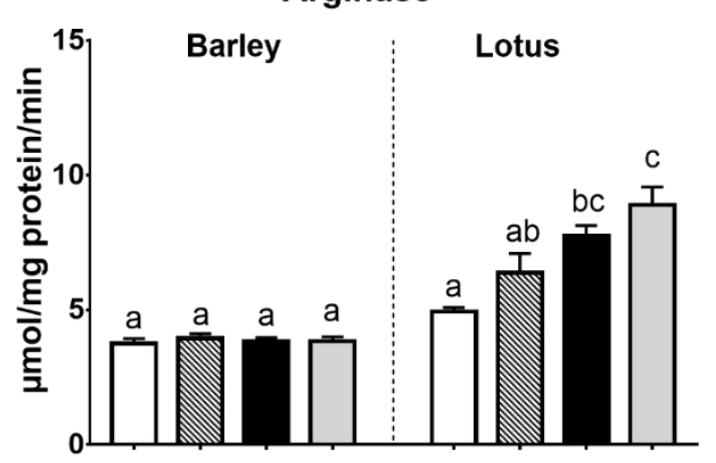

(B) Arginine

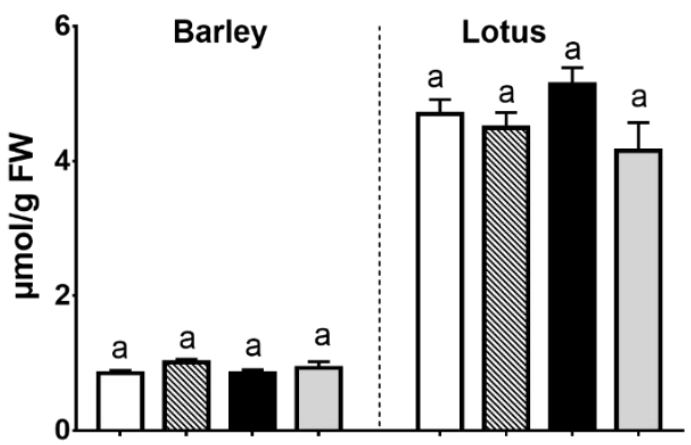

(D)

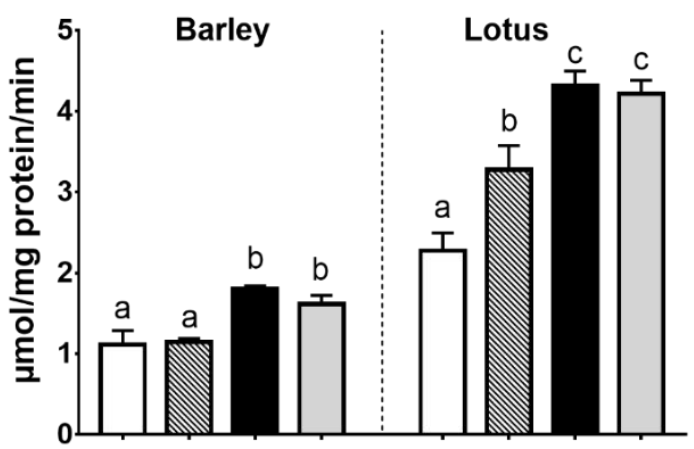

Figure 2. Proline biosynthesis (ornithine pathway). Changes in metabolic level and related enzyme activity in barley and lotus plants: impact of arbuscular mycorrhizal fungi (AMF), Al (25 mg Al kg ${ }^{-1}$ soil), or their combination. Panels show concentrations of ornithine (A), arginine (B), and the activity of arginase (C) and ornithine aminotransferase (OAT; (D)). Different letters in each graph represent significant differences between the three treatments in each species (Tukey's test; $p<0.05 ; n=5$ ).

\subsection{P5C-Pro Metabolism Cycle}

The obtained results, as shown in Figure 3, revealed that under AMF treatment, there was a significant increase in Pro only in lotus, with a slight decrease in the immediate precursor (P5C). Although there was no increase in the Pro level in barley, an increase in P5CR was recorded. In contrast, there was a significant decrease in the activity of the catabolic enzyme (ProDH) in lotus, but this decrease was little in barley (Figure 3). $\mathrm{Al}$ stress in general increased Pro in both species, with a decrease or no change in the P5C level in barley and lotus, respectively. In line with the high proline level in treated species, an increase in P5CR activity and a decrease in ProDH activity were observed. In 
all cases, AMF treatment increased the Al-stress-induced Pro increase (Figure 3). This was consistent with the observed increase and decrease in P5CR and ProDH activities in both species, respectively.

\section{$\square$ Control $\mathbf{D A M F} \square \mathrm{Al} \square \mathrm{Al}+\mathrm{AMF}$}
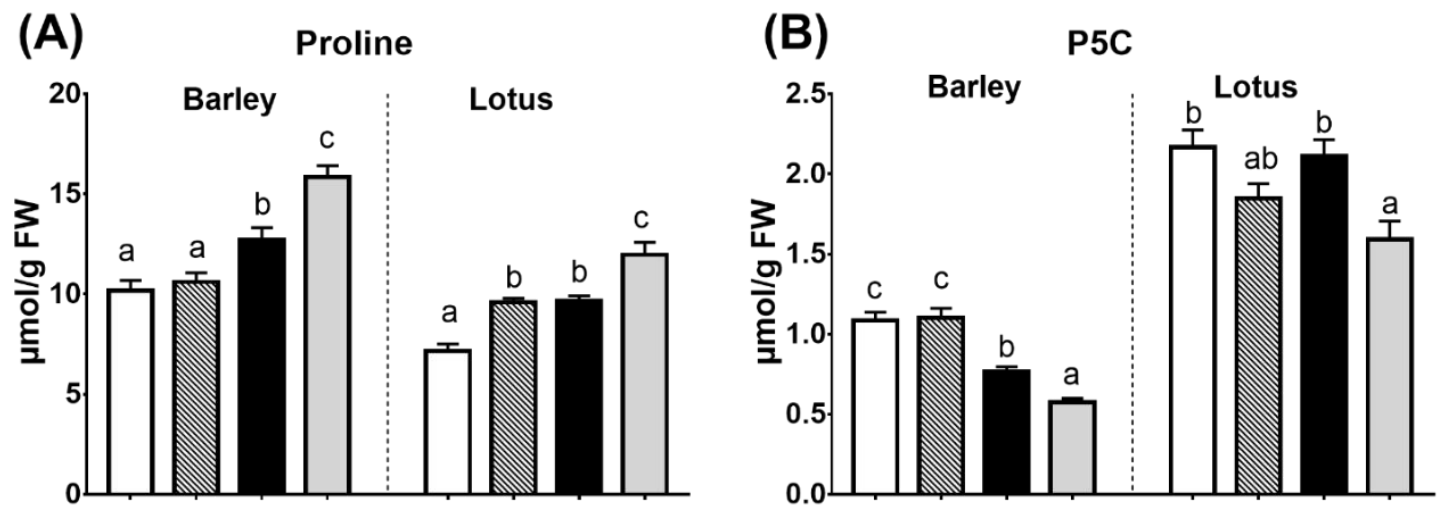

(C)

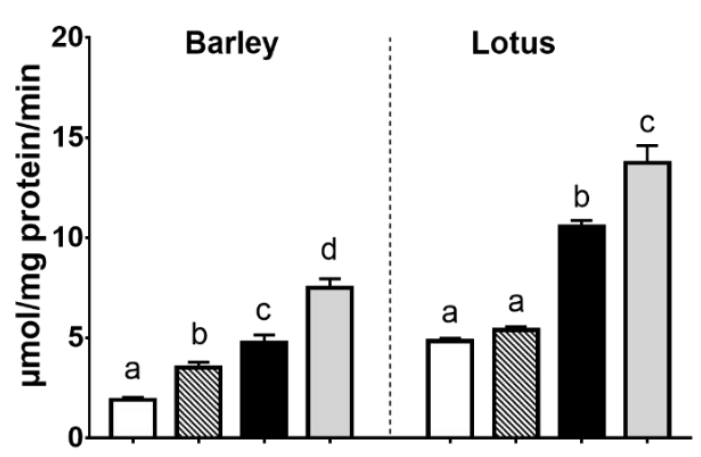

(D)

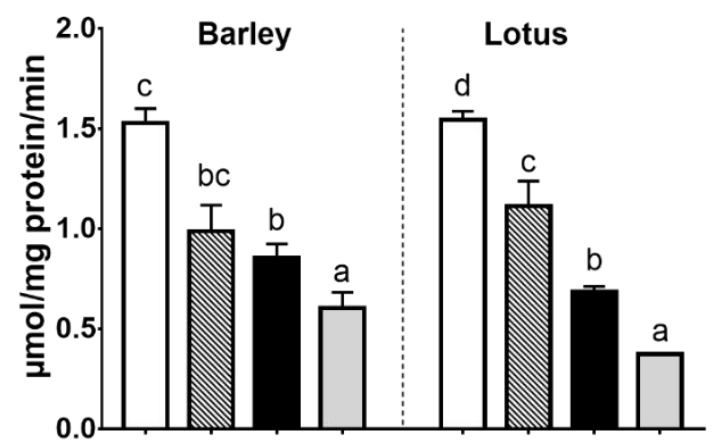

Figure 3. Pro biosynthesis (P5C-Pro metabolism cycle). Changes in metabolic level and related enzyme activities: impact of arbuscular mycorrhizal fungi (AMF), $\mathrm{Al}\left(25 \mathrm{mg} \mathrm{Al} \mathrm{kg}^{-1}\right.$ soil), or their combination. Panels show concentrations of proline (A) and its immediate precursor P5C (B) and the activity of pyrroline-5-carboxylate reductase (P5CR) (C) and proline dehydrogenase (ProDH) (D). Different letters in each graph represent significant differences between the three treatments in each species (Tukey's test; $p<0.05 ; n=5$ ).

\subsection{Nitrogen (N) Assimilation}

The obtained results (Table 3 ) revealed that AMF inoculation had no significant impact on the nitrogen content or nitrate reductase activity in both barley and lotus plants. On the contrary, under Al treatment, nitrogen content and nitrate reductase activity decreased in both plants. Interestingly, the co-inoculation of AMF with Al recovered the negative impact of Al toxicity on the nitrogen content in both plants and on nitrate reductase in lotus only.

\subsection{Hierarchical Clustering of Proline-Metabolism-Related Parameters}

Hierarchical clustering analysis showed divergences in proline metabolic relative values in AMF-treated barley and lotus plants under control and Al stress conditions (Figure 4). There were two major groups, with the first containing proline and its biosynthetic enzymes (GS, GDH, GOGAT, P5CR, arginase, and OAT) that were higher in Al-stressed plants, particularly lotus plants. In most cases, the increase in Pro biosynthetic enzymes was significantly induced by $\mathrm{AMF}$ and $\mathrm{Al}$ co-application, particularly in lotus. However, the second group contained plant growth- and physiology-related parameters, AMF col- 
onization, arbuscule number and Pro catabolic enzymes (ProDH and P5CDH), proline percussors (e.g., glutamine, glutamate, ornithine, and arginine), and nitrogen assimilation. The parameters in group 2 were in general higher in non-Al stressed plants, particularly in lotus. Moreover, AMF inculcation significantly reduced the negative impact of $\mathrm{Al}$ stress in both species.

Table 3. Nitrogen content and nitrate reductase (NR) in barley and lotus shoot under normal (control) and Al stress conditions. Values are the mean \pm standard error of five independent replicates. Different letters indicate significant changes $(p<0.05)$ between AMF alone and combined AMF + Al treatment.

\begin{tabular}{ccccccccc}
\hline \multirow{2}{*}{ Parameter } & \multicolumn{4}{c}{ Barley } & \multicolumn{3}{c}{ Lotus } \\
\cline { 2 - 8 } & Control & AMF & Al & Al + AMF & Control & AMF & Al & Al + AMF \\
\hline $\begin{array}{c}\text { Nitrogen } \\
\begin{array}{c}\text { Nitrate } \\
\text { reductase }\end{array}\end{array}$ & $218.3 \pm 12 \mathrm{c}$ & $238 \pm 17 \mathrm{c}$ & $133 \pm 15 \mathrm{a}$ & $163 \pm 21 \mathrm{~b}$ & $255 \pm 19 \mathrm{c}$ & $285 \pm 26 \mathrm{c}$ & $198 \pm 16 \mathrm{a}$ & $228 \pm 13 \mathrm{~b}$ \\
\hline
\end{tabular}

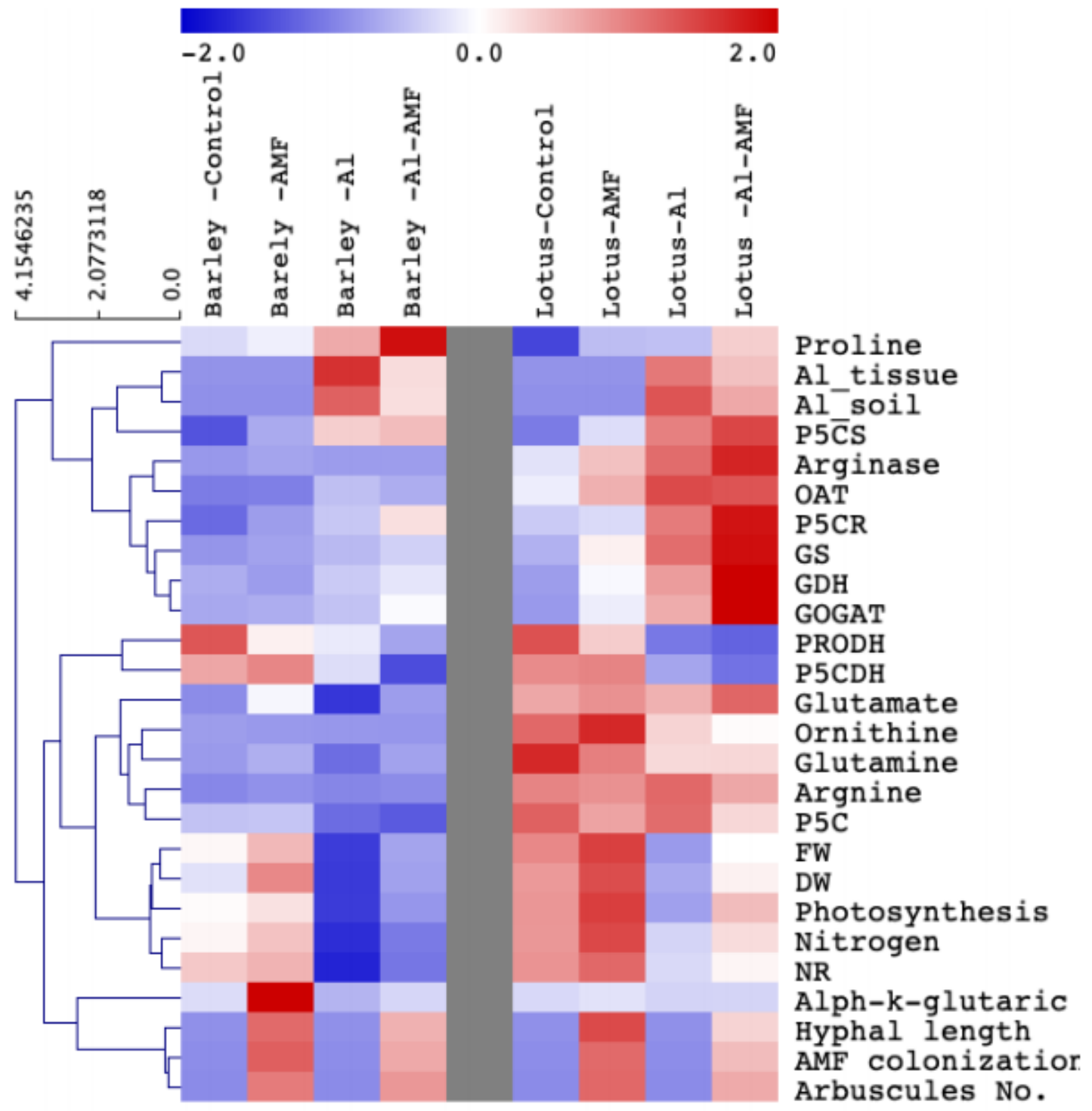

Figure 4. Hierarchical clustering of proline-metabolism-related parameters. The levels patterns are relatively demonstrated on the heatmap based on the mean value $(n=5)$ for each parameter. Red and blue color gradients indicate higher and lower levels, respectively. Full names are indicted in the legends of Figures 1-3 and Tables 1-3. 


\section{Discussion}

4.1. Al Greatly Inhibits Growth and Photosynthesis in Both Plants, with Lotus Bring More Tolerant

The accumulation of $\mathrm{Al}$ in plants is known to induce a hazardous impact at developmental, physiological, and biochemical levels. For instance, the negative effects of $\mathrm{Al}$ on plant biomass have been previously reported $[5,6,43]$. Al accumulated in the two species but to a greater extent in barley, resulting in impairment in root growth (data not shown). In contrast, lotus was less sensitive to the impact of $\mathrm{Al}$ stress compared with barley. These results suggest that uptake of $\mathrm{Al}$ by roots and/or its penetration into the stele is lower in lotus, resulting in a lower content in leaves, which can be considered a kind of adaptation mechanism whereby plants protect the photosynthetic organs from Al toxicity [44-46]. In this regard, a previous study reported that cereal plants accumulate high amounts of $\mathrm{Al}$, particularly in their roots [47]. The higher accumulation of $\mathrm{Al}$ in plant roots can induce several morphological and biochemical changes, such as deformation of root hairs and the root apex, causing inhibition of roots to uptake essential nutrients, consequently affecting plant growth [7,8]. To further understand the inhibition caused by $\mathrm{Al}$ stress on plant growth, the photosynthetic rate was measured in both treated plants (Table 2). It is well known that the photosynthesis process is extremely sensitive to heavy metal exposure [48]. As such, $\mathrm{Al}$ interferes with light absorption, electron transport, gas exchange, pigments, carbohydrates, photo-protective systems, photosynthetic enzymes, and $\mathrm{CO}_{2}$ assimilation [49-51]. A previous study demonstrated that AMF improve the growth and photosynthesis rate of C4 (Hemarthria altissima) and C3 (Leymus chinensis) species via promoting their ROS-scavenging systems $[52,53]$ or by accumulating greater osmoprotectants, such as Pro [54]. In the present study, lotus and barley plants differentially responded to $\mathrm{Al}$ stress, where the photosynthetic rate of barley was more affected compared with that of lotus. Accordingly, the fresh and dry masses of barley plants decreased under $\mathrm{Al}$ stress by $60 \%$ and $71 \%$, respectively, compared with the control plants. However, for lotus plants, the average values of dry mass and rate of photosynthesis reduced by only $46 \%$ and $53 \%$, respectively. Interestingly, AMF diminished the inhibition role of Al stress in both plant species (Table 2); therefore, biomass production increased under the effect of AMF-plant symbiosis, which might be due to the potentiality of AMF to increase nutrient uptake [53]. Moreover, the use of photosynthates could contribute to increasing the hyphal growth of AMF, which ensure symbiotic Pi acquisition by the host plant under Al stress, which, in turn, helps in maintenance of photosynthesis and C flow to the root system [20].

\subsection{AMF Decreased Al Accumulation and Alleviated its Negative Impact on Growth and Photosynthesis}

It is well known that AMF have a symbiosis relationship with plants, in which the host provides AMF with energy through carbon assimilation; therefore, environmental factors, including heavy metal stress, such as Al stress, can affect AMF by affecting the activities of their host [55]. The interaction between AMF and plants can enrich soil resources with essential nutrients that help plants to effectively respond to different environmental factors [56]. Several studies have reported the effects of environmental factors on the effectiveness of AMF in improvement of plant growth [29]; since AMF are attached to plant roots, they receive a lower amount of photosynthates under Al stress. The present study reported that mycorrhizal growth markedly decreased in lotus compared with barley under Al stress (Table 1), demonstrating that the impact of Al levels on mycorrhizal growth seems to be dependent on the plant species.

A few studies have reported that AMF colonization ameliorates $\mathrm{Al}$ toxicity, leading to improved plant growth and stress tolerance $[57,58]$. In addition to the colonization, the interaction of AMF with host roots may extend the efficacy of $\mathrm{Al}$ resistance by upregulating the resistance mechanisms of host plants, such as enhancing antioxidant defense systems and supporting osmotic adjustment [7,21]. Further, AMF could provide new mechanisms for $\mathrm{Al}$ exclusion and detoxification, such as metal immobilization in extra- and intraradical 
fungal structures $[17,20]$. Further, AMF-plant symbiosis can facilitate nutrient acquisition by altering the availability and/or speciation of $\mathrm{Al}$ in the rhizosphere [55]. In the present study, AMF treatment markedly reverted the effects of Al stress on plant growth, resulting in a significant increase in fresh and dry masses, especially in barley (Table 2). This could be related to the decrease in $\mathrm{Al}$ accumulation in plant tissues, which might be due to the ability of AMF to reduce the absorption and translocation of toxic metals by the host plants [59]. In this context, $\mathrm{Wu}$ et al. [17] reported the immobilization of chromium on the fungal surface and in the arbuscules and intraradical mycelium within mycorrhizal roots.

\subsection{Proline Metabolism in Lotus Is More Responsive to Al Than in Barley}

Proline, a multifunctional stress-induced metabolite, is reported to accumulate in mycorrhizal plants exposed to various types of abiotic stresses [7,21]. In the current study, to reveal the mechanism behind AMF-induced proline accumulation, detailed changes in proline biosynthesis and degradation pathways were investigated in host plants under $\mathrm{Al}$ toxicity. As a first species-specific response to Al stress, although the Glu pathway for Pro biosynthesis was promoted in both species, the enhancement was more pronounced in lotus (Figures 1 and 4). In the present study, AMF significantly improved P5CS activity under Al stress. This enzyme is commonly considered a key regulator of the Glu pathway [30,60]. However, our result is inconsistent with a previous study reporting that AMF seedlings show significantly lower P5CR and P5CS activities than non-inoculated seedlings [61], indicating that the decrease in Pro accumulation in AMF seedlings is closely related with the decrease in glutamate synthetic pathways and the increase in Pro catabolism. In the current study, OAT activity considerably increased only in lotus plants, suggesting a speciesspecific contribution of Pro through the Orn pathway under Al stress. At the degradation level, ProDH re-oxidizes Pro to P5C, so lower activity contributes to Pro accumulation. Inhibition of ProDH was also previously observed in other species under different stress conditions [62]. Herein, there was a pronounced increase in Pro in lotus plants, which might be due to the extra Pro supply through the Orn pathway, and a stronger inhibition of Pro degradation. The participation of each pathway in the stress-induced Pro accumulation is plant species and stressor dependent [63,64]. For instance, Pro accumulation in rice stressed by $\mathrm{Cu}$ was induced through the Orn pathway [65]. However, in tobacco grown under $\mathrm{Cu}$ and drought stress, both the Glu and Orn pathways for Pro biosynthesis were upregulated [28]. Moreover, other studies have indicated the differential accumulation of Pro in soybean and rice genotypes as being responsible for the genotype-specific tolerance to heavy metal toxicity $[65,66]$. Notably, genotype sensitivity differences to other abiotic stressors in plants have also sometimes been linked to differences in Pro levels $[59,67]$.

Since Pro metabolism is closely connected to nitrogen metabolism [68], the present study suggested that increased nitrogen assimilation in lotus improved the ability to further elevate Pro levels to increase tolerance to Al stress, consistent with previous studies reporting that the external addition of nitrogen results in elevated Pro [69,70]. In several cases, the increase in nitrogen might be due to the Orn pathway [69], supporting our speculation. AbdElgawad et al. [30] demonstrated that Pro accumulation in grasses and legumes under drought stress occurs mainly via the Glu pathway in grasses and the Orn pathway in legumes. They attributed this difference to the better nitrogen status in legumes than in grasses. To further validate our hypothesis, we measured the $\mathrm{N}$ content and nitrate reductase activity in both barley and lotus plants. We found higher $\mathrm{N}$ content and NR activity in lotus, especially under stress conditions. NR activity, $\mathrm{N}$ levels, and N/C ratios were less reduced in the tolerant rye line, which showed an upregulated Orn pathway [71]. Overall, Pro content strongly increased in barley and lotus, although through different mechanisms, and possibly is directly linked with the $\mathrm{N}$ status in plants.

AMF further enhanced Pro accumulation in Al-treated plants through upregulation of the glutamate pathway and downregulation of Pro degradation. Proline, the key osmolyte contributing toward osmotic adjustment, was comparatively higher in AMF-treated plants enduring Al stress. The higher Pro levels in AMF-treated plants were due to upregulation 
of the glutamate pathway and downregulation of Pro degradation. Further, such enhanced proline accumulation was consistent with the improved $\mathrm{N}$ content in mycorrhizal plants grown under $\mathrm{Al}$ stress (Table 3). These results reveal that mycorrhizal-treated plants acquire higher osmotic adjustment to support tolerance to Al stress, which is likely related to Pro. Similarly, a higher Pro accumulation in AMF plants under drought was observed in Lactuca sativa [72], Oryza sativa [73], and Macadamia tetraphylla [74]. AMF colonization is widely believed to stimulate mineral nutrient uptake in plants, e.g., N, P, and K [16]. In this regard, AMF are effectively used to enhance the biological nitrogen fixation and phosphate solubilization processes in soil and the rhizosphere [75]. In addition, mycorrhizal inoculation significantly enhanced dehydrogenase activity, which could be attributed to the ability of AMF to improve the physical and chemical properties of soil, especially the soil structure, enhancing the organic matter decomposition and remobilizing nutrients, including nitrogen, in the rhizosphere and soil [29]. Due to the close connection between Pro and N metabolism [68], enhanced N uptake could enhance Pro accumulation Pro [69,70].

\section{Conclusions}

The presence of $\mathrm{Al}$ in the soil increases its uptake, which consequently impairs barley and lotus growth and photosynthesis; however, lotus is more tolerant. To reduce Al toxicity, both plants species accumulate high levels of Pro, with some species-specific responses in Pro biosynthesis pathways. Inoculation with AMF reduces the levels of aluminum accumulation in plant tissues and consequently recovers the negative impact of $\mathrm{Al}$ on growth and the rate of photosynthesis, especially in barley. Further, AMF treatment promotes the accumulation of Pro and its percussors through activating Pro biosynthesis and reducing its catabolism. The use of AMF for inoculation of barley and lotus plants demonstrates great beneficial potential for protecting plants against $\mathrm{Al}$ stress. This knowledge can help plant future crops in soils contaminated by heavy metals, which today are considered useless for agriculture.

Author Contributions: Conceptualization, A.M.S. and H.A.E.; methodology, M.O.A. and H.A.E.; software, A.M.S.; validation, R.L.S., M.S.S., A.M.E.-S. and A.E.M.; formal analysis, M.O.A.; investigation, H.A.E.; resources, M.O.A., A.M.E.-S.; data curation, A.M.S.; writing-original draft preparation, R.L.S., M.S.S. and A.E.M.; writing-review and editing, A.M.S. and H.A.E.; visualization, A.M.S.; supervision, H.A.E.; project administration, M.O.A.; funding acquisition, A.E.M. All authors have read and agreed to the published version of the manuscript.

Funding: This research was funded by the Deanship of Scientific Research at Princess Nourah bint Abdulrahman University through the fast-track research funding program.

Institutional Review Board Statement: Not applicable.

Informed Consent Statement: Not applicable.

Data Availability Statement: Data presented in this study are available on reasonable request.

Acknowledgments: This research was funded by the Deanship of Scientific Research at Princess Nourah bint Abdulrahman University through the fast-track research funding program.

Conflicts of Interest: The authors declare no conflict of interest.

\section{References}

1. Singh, R.; Gupta, V.; Mishra, A.; Gupta, R. Heavy metals and living systems: An overview. Indian J. Pharmacol. 2011, 43, $246-253$. [CrossRef]

2. de Sousa, A.; Saleh, A.M.; Habeeb, T.H.; Hassan, Y.M.; Zrieq, R.; Wadaan, M.A.M.; Hozzein, W.N.; Selim, S.; Matos, M.; AbdElgawad, H. Silicon dioxide nanoparticles ameliorate the phytotoxic hazards of aluminum in maize grown on acidic soil. Sci. Total Environ. 2019, 693, 133636. [CrossRef] [PubMed]

3. Dal Molin, S.J.; Ernani, P.R.; Gerber, J.M. Soil acidification and nitrogen release following application of nitrogen fertilizers. Commun. Soil Sci. Plant Anal. 2020, 51, 2551-2558. [CrossRef] 
4. $\quad$ Pierre, W.H.; Webb, J.R.; Shrader, W.D. Quantitative Effects of Nitrogen Fertilizer on the Development and Downward Movement of Soil Acidity in Relation to Level of Fertilization and Crop Removal in a Continuous Corn Cropping System1. Agron. J. 1971, 63, 291-297. [CrossRef]

5. Yamamoto, Y. Aluminum toxicity in plant cells: Mechanisms of cell death and inhibition of cell elongation. Soil Sci. Plant Nutr. 2019, 65, 41-55. [CrossRef]

6. Egerton-Warburton, L. Aluminum-Tolerant Pisolithus Ectomycorrhizas Confer Increased Growth, Mineral Nutrition, and Metal Tolerance to Eucalyptus in Acidic Mine Spoil. Appl. Environ. Soil Sci. 2015, 2015, 803821. [CrossRef]

7. Pirzadah, T.B.; Malik, B.; Tahir, I.; Rehman, R.U.; Hakeem, K.R.; Alharby, H.F. Aluminium stress modulates the osmolytes and enzyme defense system in Fagopyrum species. Plant Physiol. Biochem. 2019, 144, 178-186. [CrossRef]

8. Singh, S.; Tripathi, D.K.; Singh, S.; Sharma, S.; Dubey, N.K.; Chauhan, D.K.; Vaculík, M. Toxicity of aluminium on various levels of plant cells and organism: A review. Environ. Exp. Bot. 2017, 137, 177-193. [CrossRef]

9. Kochian, L.; Piñeros, M.; Hoekenga, O. The Physiology, Genetics and Molecular Biology of Plant Aluminum Resistance and Toxicity. Plant Soil 2005, 274, 175-195. [CrossRef]

10. Panda, S.K.; Baluška, F.; Matsumoto, H. Aluminum stress signaling in plants. Plant Signal. Behav. 2009, 4, 592-597. [CrossRef]

11. Blumenthal, M.J.; McGraw, R.L. Lotus adaptation, use, and management. Trefoil Sci. Technol. Lotus 1999, 28, 97-119.

12. Ma, J.F.; Zheng, S.J.; Li, X.F.; Takeda, K.; Matsumoto, H. A rapid hydroponic screening for aluminium tolerance in barley. Plant Soil 1997, 191, 133-137. [CrossRef]

13. Mitra, D.; Djebaili, R.; Pellegrini, M.; Mahakur, B.; Sarker, A.; Chaudhary, P.; Khoshru, B.; Del Gallo, M.; Kitouni, M.; Barik, D.P.; et al. Arbuscular mycorrhizal symbiosis: Plant growth improvement and induction of resistance under stressful conditions. $J$. Plant Nutr. 2021, 1993-2028. [CrossRef]

14. Riaz, M.; Kamran, M.; Fang, Y.; Wang, Q.; Cao, H.; Yang, G.; Deng, L.; Wang, Y.; Zhou, Y.; Anastopoulos, I.; et al. Arbuscular mycorrhizal fungi-induced mitigation of heavy metal phytotoxicity in metal contaminated soils: A critical review. J. Hazard. Mater. 2021, 402, 123919. [CrossRef]

15. Higo, M.; Isobe, K.; Kang, D.-J.; Ujiie, K.; Drijber, R.A.; Ishii, R. Inoculation with arbuscular mycorrhizal fungi or crop rotation with mycorrhizal plants improves the growth of maize in limed acid sulfate soil. Plant Prod. Sci. 2010, 13, 74-79. [CrossRef]

16. Begum, N.; Qin, C.; Ahanger, M.A.; Raza, S.; Khan, M.I.; Ashraf, M.; Ahmed, N.; Zhang, L. Role of Arbuscular Mycorrhizal Fungi in Plant Growth Regulation: Implications in Abiotic Stress Tolerance. Front. Plant Sci. 2019, 10. [CrossRef]

17. Wu, S.; Zhang, X.; Sun, Y.; Wu, Z.; Li, T.; Hu, Y.; Lv, J.; Li, G.; Zhang, Z.; Zhang, J.; et al. Chromium immobilization by extra-and intraradical fungal structures of arbuscular mycorrhizal symbioses. J. Hazard. Mater. 2016, 316, 34-42. [CrossRef]

18. Ferrol, N.; Tamayo, E.; Vargas, P. The heavy metal paradox in arbuscular mycorrhizas: From mechanisms to biotechnological applications. J. Exp. Bot. 2016, 67, 6253-6265. [CrossRef] [PubMed]

19. Higo, M.; Kang, D.-J.; Isobe, K. First report of community dynamics of arbuscular mycorrhizal fungi in radiocesium degradation lands after the Fukushima-Daiichi Nuclear disaster in Japan. Sci. Rep. 2019, 9, 8240. [CrossRef]

20. Seguel, A.; Cumming, J.R.; Klugh-Stewart, K.; Cornejo, P.; Borie, F. The role of arbuscular mycorrhizas in decreasing aluminium phytotoxicity in acidic soils: A review. Mycorrhiza 2013, 23, 167-183. [CrossRef] [PubMed]

21. Vergara, C.; Araujo, K.E.C.; de Souza, S.R.; Schultz, N.; Saggin, J.O.J.; Sperandio, M.V.L.; Zilli, J.É. Plant-mycorrhizal fungi interaction and response to inoculation with different growth-promoting fungi. Pesqui. Agropecuária Bras. 2019, 54. [CrossRef]

22. Kishor, K.; Polavarapu, B.; Hima, K.P.; Sunita, M.S.L.; Sreenivasulu, N. Role of proline in cell wall synthesis and plant development and its implications in plant ontogeny. Front. Plant Sci. 2015, 6, 544. [CrossRef]

23. Szabados, L.; Savouré, A. Proline: A multifunctional amino acid. Trends Plant Sci. 2010, 15, 89-97. [CrossRef]

24. Liang, X.; Zhang, L.; Natarajan, S.K.; Becker, D.F. Proline mechanisms of stress survival. Antioxid. Redox Signal. 2013, 19, 998-1011. [CrossRef]

25. Shinde, S.; Villamor, J.G.; Lin, W.; Sharma, S.; Verslues, P.E. Proline Coordination with Fatty Acid Synthesis and Redox Metabolism of Chloroplast and Mitochondria. Plant Physiol. 2016, 172, 1074-1088. [CrossRef] [PubMed]

26. Kavi, K.P.B.; Sreenivasulu, N. Is proline accumulation per se correlated with stress tolerance or is proline homeostasis a more critical issue? Plant. Cell Environ. 2014, 37, 300-311. [CrossRef] [PubMed]

27. Meena, M.; Divyanshu, K.; Kumar, S.; Swapnil, P.; Zehra, A.; Shukla, V.; Yadav, M.; Upadhyay, R.S. Regulation of L-proline biosynthesis, signal transduction, transport, accumulation and its vital role in plants during variable environmental conditions. Heliyon 2019, 5, e02952. [CrossRef]

28. Ku, H.-M.; Tan, C.-W.; Su, Y.-S.; Chiu, C.-Y.; Chen, C.-T.; Jan, F.-J. The effect of water deficit and excess copper on proline metabolism in Nicotiana benthamiana. Biol. Plant. 2012, 56, 337-343. [CrossRef]

29. El-Sawah, A.M.; El-Keblawy, A.; Ali, D.F.I.; Ibrahim, H.M.; El-Sheikh, M.A.; Sharma, A.; Alhaj Hamoud, Y.; Shaghaleh, H.; Brestic, M.; Skalicky, M.; et al. Arbuscular Mycorrhizal Fungi and Plant Growth-Promoting Rhizobacteria Enhance Soil Key Enzymes, Plant Growth, Seed Yield, and Qualitative Attributes of Guar. Agriculture 2021, 11, 194. [CrossRef]

30. Abdelgawad, H.; Farfan-vignolo, E.R.; De Vos, D.; Asard, H. Elevated $\mathrm{CO}_{2}$ mitigates drought and temperature-induced oxidative stress differently in grasses and legumes. Plant Sci. 2015, 231, 1-10. [CrossRef] [PubMed]

31. Phillips, J.M.; Hayman, D.S. Improved procedures for clearing roots and staining parasitic and vesicular-arbuscular mycorrhizal fungi for rapid assessment of infection. Trans. Br. Mycol. Soc. 1970, 55, 158-161. [CrossRef] 
32. Giovannetti, M.; Mosse, B. An evaluation of techniques for measuring vesicular arbuscular mycorrhizal infection in roots. New Phytol. 1980, 84, 489-500. [CrossRef]

33. Andrade, G.; Mihara, K.L.; Linderman, R.G.; Bethlenfalvay, G.J. Bacteria from rhizosphere and hyphosphere soils of different arbuscular-mycorrhizal fungi. Plant Soil 1997, 192, 71-79. [CrossRef]

34. Giannakoula, A.; Moustakas, M.; Mylona, P.; Papadakis, I.; Yupsanis, T. Aluminum tolerance in maize is correlated with increased levels of mineral nutrients, carbohydrates and proline, and decreased levels of lipid peroxidation and Al accumulation. J. Plant Physiol. 2008, 165, 385-396. [CrossRef]

35. AbdElgawad, H.; Peshev, D.; Zinta, G.; den Ende, W.; Janssens, I.A.; Asard, H. Climate extreme effects on the chemical composition of temperate grassland species under ambient and elevated CO2: A comparison of fructan and non-fructan accumulators. PLoS ONE 2014, 9, e92044. [CrossRef] [PubMed]

36. Temple, S.J.; Kunjibettu, S.; Roche, D.; Sengupta-Gopalan, C. Total glutamine synthetase activity during soybean nodule development is controlled at the level of transcription and holoprotein turnover. Plant Physiol. 1996, 112, 1723-1733. [CrossRef]

37. Zhang, M.; Tanaka, T.; Ikura, M. Calcium-induced conformational transition revealed by the solution structure of apo calmodulin. Nat. Struct. Biol. 1995, 2, 758-767. [CrossRef] [PubMed]

38. Lutts, S.; Majerus, V.; Kinet, J.M. NaCl effects on proline metabolism in rice (Oryza sativa) seedlings. Physiol. Plant. 1999, 105, 450-458. [CrossRef]

39. Sakuraba, Y.; Schelbert, S.; Park, S.-Y.; Han, S.-H.; Lee, B.-D.; Andrès, C.B.; Kessler, F.; Hörtensteiner, S.; Paek, N.-C. STAYGREEN and Chlorophyll Catabolic Enzymes Interact at Light-Harvesting Complex II for Chlorophyll Detoxification during Leaf Senescence in Arabidopsis. Plant Cell 2012, 24, 507-518. [CrossRef]

40. Charest, C.; Ton, P.C. Cold acclimation of wheat (Triticum aestivum): Properties of enzymes involved in proline metabolism. Physiol. Plant. 1990, 80, 159-168. [CrossRef]

41. Nuzum, C.T.S.P.J. The Urea Cycle; Grisolía, S., Mayor, F.B.R., Eds.; John William and Sons: New York, NY, USA, 1976.

42. AbdElgawad, H.; Abuelsoud, W.; Madany, M.M.Y.; Selim, S.; Zinta, G.; Mousa, A.S.M.; Hozzein, W.N. Actinomycetes Enrich Soil Rhizosphere and Improve Seed Quality as well as Productivity of Legumes by Boosting Nitrogen Availability and Metabolism. Biomolecules 2020, 10, 1675. [CrossRef] [PubMed]

43. Peixoto, H.P.; Da Matta, F.M.; Da Matta, J.C. Responses of the photosynthetic apparatus to aluminum stress in two sorghum cultivars. J. Plant Nutr. 2002, 25, 821-832. [CrossRef]

44. Saleh, A.M.; Hassan, Y.M.; Habeeb, T.H.; Alkhalaf, A.A.; Hozzein, W.N.; Selim, S.; Abdelgawad, H. Interactive effects of mercuric oxide nanoparticles and future climate CO 2 on maize plant. J. Hazard. Mater. 2021, 401, 123849. [CrossRef] [PubMed]

45. Graham, C.J. Nonstructural carbohydrate and prunasin composition of peach seedlings fertilized with different nitrogen sources and aluminum. Sci. Hortic. 2002, 94, 21-32. [CrossRef]

46. Jiang, H.-X.; Chen, L.-S.; Zheng, J.-G.; Han, S.; Tang, N.; Smith, B.R. Aluminum-induced effects on Photosystem II photochemistry in Citrus leaves assessed by the chlorophyll a fluorescence transient. Tree Physiol. 2008, 28, 1863-1871. [CrossRef]

47. Kochian, L.V. Cellular mechanisms of aluminum toxicity and resistance in plants. Annu. Rev. Plant Physiol. Plant Mol. Biol. 1995, 46. [CrossRef]

48. Kohlbrenner, W.E.; Cross, R.L. The mode of inhibition of oxidative phosphorylation by efrapeptin (A23871): Measurement of substrate effects on rates of inactivation by a tight-binding inhibitor. Arch. Biochem. Biophys. 1979, 198, 598-607. [CrossRef]

49. Ashraf, M.; Harris, P.J.C. Photosynthesis under stressful environments: An overview. Photosynthetica 2013, 51, 163-190. [CrossRef]

50. Pereira, W.E.; de Siqueira, D.L.; Martínez, C.A.; Puiatti, M. Gas exchange and chlorophyll fluorescence in four citrus rootstocks under aluminium stress. J. Plant Physiol. 2000, 157, 513-520. [CrossRef]

51. Leal-Alvarado, D.A.; Espadas-Gil, F.; Sáenz-Carbonell, L.; Talavera-May, C.; Santamaría, J.M. Lead accumulation reduces photosynthesis in the lead hyper-accumulator Salvinia minima Baker by affecting the cell membrane and inducing stomatal closure. Aquat. Toxicol. 2016, 171, 37-47. [CrossRef]

52. Li, X.; He, M.; Guo, J.; Cao, T. Upregulation of circular RNA circ-ERBB2 predicts unfavorable prognosis and facilitates the progression of gastric cancer via miR-503/CACUL1 and miR-637/MMP-19 signaling. Biochem. Biophys. Res. Commun. 2019, 511, 926-930. [CrossRef] [PubMed]

53. Sheteiwy, M.S.; Shao, H.; Qi, W.; Daly, P.; Sharma, A.; Shaghaleh, H.; Hamoud, Y.A.; El-Esawi, M.A.; Pan, R.; Wan, Q.; et al. Seed priming and foliar application with jasmonic acid enhance salinity stress tolerance of soybean (Glycine max L.) seedlings. J. Sci. Food Agric. 2021, 101, 2027-2041. [CrossRef]

54. Scagel, C.F.; Bryla, D.; Lee, J. Salt Exclusion and Mycorrhizal Symbiosis Increase Tolerance to $\mathrm{NaCl}$ and $\mathrm{CaCl} 2 \mathrm{Salinity}$ in “Siam Queen" Basil. Hortic. Sci. Publ. Am. Soc. Hortic. Sci. 2017, 52, 278-287. [CrossRef]

55. Cumming, J.R.; Ning, J. Arbuscular mycorrhizal fungi enhance aluminium resistance of broomsedge (Andropogon virginicus L.). J. Exp. Bot. 2003, 54, 1447-1459. [CrossRef] [PubMed]

56. Shi, S.; Liang, Y.; Ang, E.L.; Zhao, H. Delta Integration CRISPR-Cas (Di-CRISPR) in Saccharomyces cerevisiae. In Microbial Metabolic Engineering: Methods and Protocols; Santos, C.N.S., Ajikumar, P.K., Eds.; Springer: New York, NY, USA, 2019 ; pp. 73-91. ISBN 978-1-4939-9142-6.

57. Rufyikiri, G.; Nootens, D.; Dufey, J.E.; Delvaux, B. Effect of aluminium on bananas (Musa spp.) cultivated in acid solutions. I. Plant growth and chemical composition. Fruits 2000, 55, 367-379. 
58. Lux, H.B.; Cumming, J.R. Mycorrhizae confer aluminum resistance to tulip-poplar seedlings. Can. J. For. Res. $2001,31,694-702$. [CrossRef]

59. Yang, W.; Weng, P.J.; Gao, Y. A new paradigm of DNA synthesis: Three-metal-ion catalysis. Cell Biosci. 2016, 6, 51. [CrossRef]

60. Wang, L.; Li, H.; Zhao, C.; Li, S.; Kong, L.; Wu, W.; Kong, W.; Liu, Y.; Wei, Y.; Zhu, J.-K.; et al. The inhibition of protein translation mediated by AtGCN1 is essential for cold tolerance in Arabidopsis thaliana. Plant. Cell Environ. 2017, 40, 56-68. [CrossRef]

61. Wu, Q.-S.; Srivastava, A.K.; Zou, Y.-N. AMF-induced tolerance to drought stress in citrus: A review. Sci. Hortic. 2013, 164, 77-87. [CrossRef]

62. Verslues, P.E.; Sharma, S. Proline metabolism and its implications for plant-environment interaction. Arab. Book 2010, 8, e0140. [CrossRef]

63. Kishor, P.B.K.; Sangam, S.; Amrutha, R.N.; Laxmi, P.S.; Naidu, K.R.; Rao, K.; Rao, S.; Reddy, K.J.; Theriappan, P.; Sreenivasulu, N. Regulation of proline biosynthesis, degradation, uptake and transport in higher plants: Its implications in plant growth and abiotic stress tolerance. Curr. Sci. 2005, 88, 424-438.

64. Yang, J.; Zhang, N.; Ma, C.; Qu, Y.; Si, H.; Wang, D. Prediction and verification of microRNAs related to proline accumulation under drought stress in potato. Comput. Biol. Chem. 2013, 46, 48-54. [CrossRef] [PubMed]

65. Chen, C.; Chen, L.-M.; Lin, C.-C.; Kao, C.-H. Regulation of proline accumulation in detached rice leaves exposed to excess copper. Plant Sci. 2001, 160, 283-290. [CrossRef]

66. Zemanová, V.; Pavlík, M.; Pavlíková, D.; Tlustoš, P. The changes of contents of selected free amino acids associated with cadmium stress in Noccaea caerulescens and Arabidopsis halleri. Plant Soil Environ. 2013, 59, 417-422. [CrossRef]

67. Kumar, P.; Dwivedi, N. Proline Catalyzed $\alpha$-Aminoxylation Reaction in the Synthesis of Biologically Active Compounds. Acc. Chem. Res. 2013, 46, 289-299. [CrossRef] [PubMed]

68. Hildebrandt, T.M.; Nunes Nesi, A.; Araújo, W.L.; Braun, H.P. Amino Acid Catabolism in Plants. Mol. Plant 2015, 8, 1563-1579. [CrossRef]

69. Sánchez, E.; López-Lefebre, L.R.; García, P.C.; Rivero, R.M.; Ruiz, J.M.; Romero, L. Proline metabolism in response to highest nitrogen dosages in green bean plants (Phaseolus vulgaris L. cv. Strike). J. Plant Physiol. 2001, 158, 593-598. [CrossRef]

70. Singh, M.; Singh, V.P.; Prasad, S.M. Nitrogen modifies $\mathrm{NaCl}$ toxicity in eggplant seedlings: Assessment of chlorophyll a fluorescence, antioxidative response and proline metabolism. Biocatal. Agric. Biotechnol. 2016, 7, 76-86. [CrossRef]

71. de Sousa, A.; AbdElgawad, H.; Fidalgo, F.; Teixeira, J.; Matos, M.; Hamed, B.A.; Selim, S.; Hozzein, W.N.; Beemster, G.T.S.; Asard, $\mathrm{H}$. Al exposure increases proline levels by different pathways in an Al-sensitive and an Al-tolerant rye genotype. Sci. Rep. 2020, 10, 16401. [CrossRef]

72. Ruiz-Lozano, J.M.; Azcón, R.; Palma, J.M. Superoxide dismutase activity in arbuscular mycorrhizal Lactuca sativa plants subjected to drought stress. New Phytol. 1996, 134, 327-333. [CrossRef]

73. Ruíz-Sánchez, M.; Armada, E.; Muñoz, Y.; de Salamone, I.E.G.; Aroca, R.; Ruíz-Lozano, J.M.; Azcón, R. Azospirillum and arbuscular mycorrhizal colonization enhance rice growth and physiological traits under well-watered and drought conditions. $J$. Plant Physiol. 2011, 168, 1031-1037. [CrossRef] [PubMed]

74. Yooyongwech, S.; Phaukinsang, N.; Cha-Um, S.; Supaibulwattana, K. Arbuscular mycorrhiza improved growth performance in Macadamia tetraphylla L. Grown under water deficit stress involves soluble sugar and proline accumulation. Plant Growth Regul. 2013, 69. [CrossRef]

75. Moradi, T.Z.; Iranbakhsh, A.; Mehregan, I.; Ahmadvand, R. Impact of arbuscular mycorrhizal fungi (AMF) on gene expression of some cell wall and membrane elements of wheat (Triticum aestivum L.) under water deficit using transcriptome analysis. Physiol. Mol. Biol. Plants 2020, 26, 143-162. [CrossRef] [PubMed] 